\title{
Whallife of Madeira and the Canary Islands
}

A Photographic Field Guide to Birds, Mammals, Reptiles, Amphibians, Dragonflies and Butterflies 
Copyright ( 2018 by Princeton University Press

Published by Princeton University Press,

41 William Street, Princeton, New Jersey 08540

In the United Kingdom: Princeton University Press, 6 Oxford Street, Woodstock, Oxfordshire OX20 1TR

press.princeton.edu

\section{All Rights Reserved}

ISBN (pbk.) 978-0-691-17076-3

British Library Cataloging-in-Publication Data is available

Library of Congress Control Number 2017956537

This book has been composed in Minion Pro and Myriad Pro

Printed on acid-free paper. $\infty$

Printed in China

Production and design by WILDGuides Ltd., Old Basing, Hampshire UK. 